
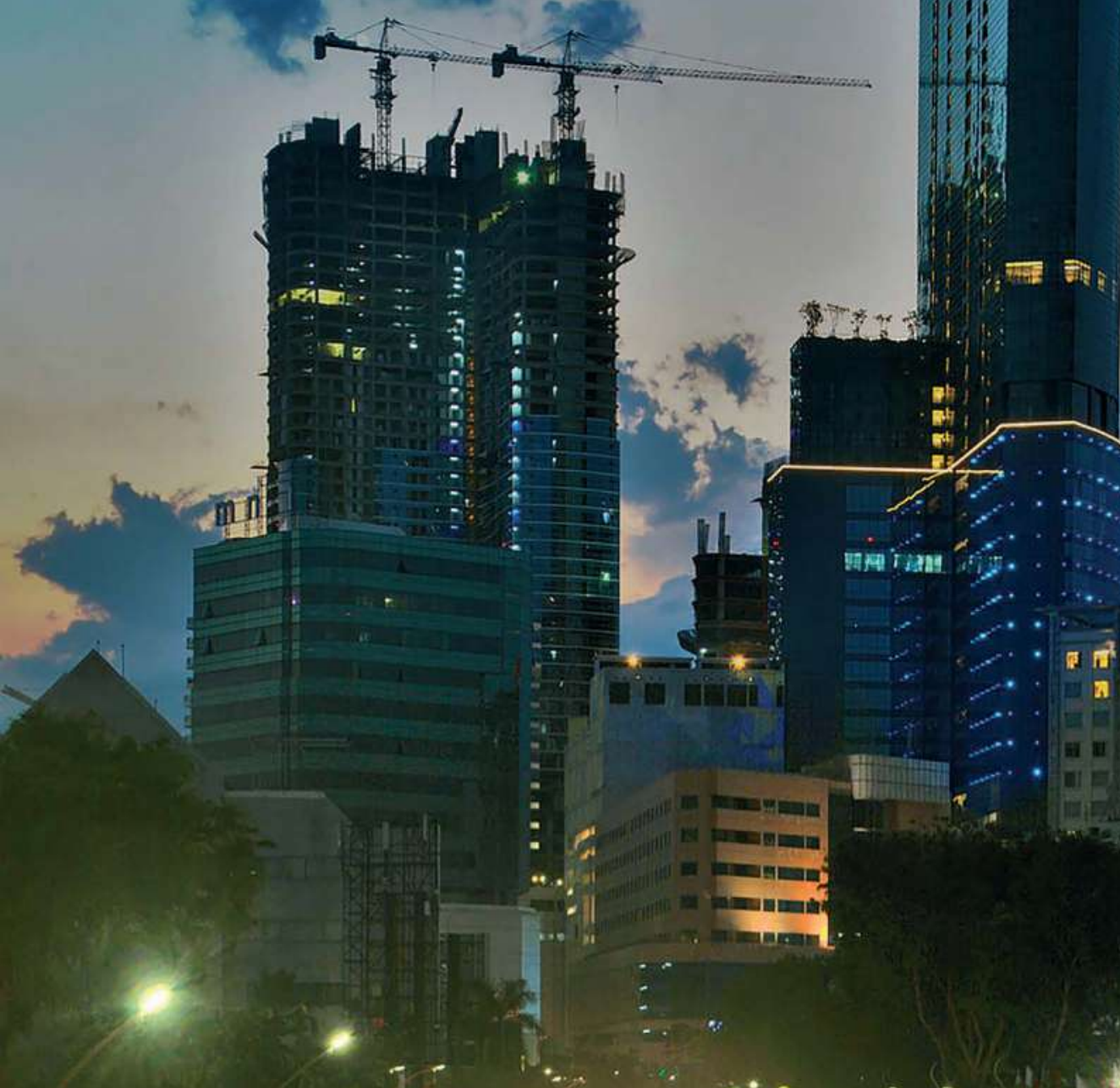

\section{Editors}

Badri Munir Sukoco

Rahmat Heru Setianto Nidya Ayu Arina Ade Gafar Abdullah Asep Bayu Nandiyanto Ratih Hurriyati

\section{Increasing Management Relevance \\ and}

\section{CPD \\ CERTIFIED

(ci. C) CRC Press

A BALKEMA BOOK 
PROCEEDINGS OF THE $2^{\text {ND }}$ GLOBAL CONFERENCE ON BUSINESS, MANAGEMENT AND ENTREPRENEURSHIP (GC-BME 2017), AUGUST 9, 2017, UNIVERSITAS AIRLANGGA, SURABAYA, INDONESIA

\section{Increasing Management Relevance and Competitiveness}

Editors

Badri Munir Sukoco, Rahmat Heru Setianto \& Nidya Ayu Arina Universitas Airlangga, Indonesia

Ade Gafar Abdullah, Asep Bayu Nandiyanto \& Ratih Hurriyati Universitas Pendidikan, Indonesia

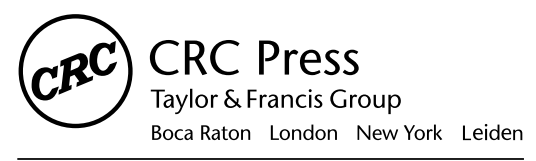

CRC Press is an imprint of the

Taylor \& Francis Group, an informa business

A BALKEMA BOOK 
CRC Press/Balkema is an imprint of the Taylor \& Francis Group, an informa business

(C) 2018 Taylor \& Francis Group, London, UK

Typeset by V Publishing Solutions Pvt Ltd., Chennai, India Printed and bound in Great Britain by CPI Group (UK) Ltd, Croydon, CR0 4YY

All rights reserved. No part of this publication or the information contained herein may be reproduced, stored in a retrieval system, or transmitted in any form or by any means, electronic, mechanical, by photocopying, recording or otherwise, without written prior permission from the publisher.

Although all care is taken to ensure integrity and the quality of this publication and the information herein, no responsibility is assumed by the publishers nor the author for any damage to the property or persons as a result of operation or use of this publication and/or the information contained herein.

Published by: CRC Press/Balkema

Schipholweg 107C, 2316 XC Leiden, The Netherlands

e-mail: Pub.NL@taylorandfrancis.com

www.crcpress.com - www.taylorandfrancis.com

ISBN: 978-0-8153-7455-8 (Hbk)

ISBN: 978-1-351-24189-2 (eBook) 


\section{Table of contents}

Preface $\quad$ xi

$\begin{array}{lc}\text { Acknowledgements } & \text { xiii }\end{array}$

$\begin{array}{ll}\text { Organizing committees } & \mathrm{XV}\end{array}$

Strategic management, entrepreneurship and contemporary issues

Governance of financial intangible success factors: An option in building business resilience and sustainability

P. Sugito

The influences of the alliance learning process and entrepreneurial orientation on the strategic alliance performance of Indonesian construction companies R. Handayani \& R. Dyah Kusumastuti

Assessing necessity and opportunity-based entrepreneurship: An analysis of demographic characteristics, propensity for new ventures and entrepreneurial motivation (a study of labor forces and entrepreneurs in Padang, Indonesia)

H. Rahman \& D. Lesmana

Critical assessment on zakat management: Zakat scorecard model

T. Widiastuti, S. Herianingrum \& I. Mawardi

Investigating entrepreneurial orientation impact on project performance in highly regulated industry: A case of renewable power industry in Indonesia

F.A. Firman, R.D. Kusumastuti, H.T. Kurniawan \& I.M. Ruky

How to survive in the modern era: Integrated local entrepreneurs, the traditional market and the modern store

P.P.D. Astuti, Y. Setyowati \& A.A.G.S. Utama

xi iii

XV

The influence of Islamic service quality toward bank customer loyalty and satisfaction of

BRISyariah Surabaya

M.Q. Fauzi, S. Herianingrum, T. Widiastuti \& R. P. Putra

Management accounting practices in micro enterprises in the Sleman Regency, Daerah

Istimewa Yogyakarta

A.C. Laksmi \& A.P. Putra

The power of finance: The dynamics of female entrepreneurs in fulfilling their financial needs

M.R. Rita, S. Wahyudi \& H. Muharam

Entrepreneurial orientation in a family business group: The role of the corporate center and its effect on business unit performance

O. Pendrian, K.A. Karnen, R. Rachmawati \& R.D. Kusumastuti

Developing entrepreneurship for the performing arts community through an art incubation model

J. Masunah \& R. Milyartini

Capability to contest on market performance

61

B. M. Sukoco \& R. R. Maulana 
The influence of the socio-economic status of parents toward entrepreneurial attitudes H. Mulyadi, M. Arief Ramdhany \& S. Sulastri

Analysis of the factors affecting the elected mode of transportation for workers using an analytical hierarchy process

E. Mahpudin \& H. Sulistiyo

71

75

Multidimensional approach for assessing service quality in the service industry

Y.D. Lestari

The influence of entrepreneurship orientation and management capability on performance of small and medium enterprises in Bogor

A. Setyo Pranowo, H. Hari Mulyadi, Z. Musannip Efendi Siregar \&

Y. Hendayana

The influence of family factors on expatriate performance

N. Kartika

Is firm size an important determinant for firms in establishing political connections?

N.N. Amorita, D. Agustia \& I. Harymawan

Integration of corporate social responsibility and resource based theory to create

and capture value

N. Nandang \& H. Mulyadi

Organizational behavior, leadership and human resources management

Superior performance model of human resources

T. Yuniarsih, Disman \& M.D. Sugiharto

The impact of fiscal decentralization on economic growth and manpower absorbed at districts/cities in South Kalimantan Province

Muzdalifah \& R. Purwono

Work-family conflict and satisfactions: A job demand-resources model perspective

J. Sulistiawan

Building employee engagement through transformational leadership, psychological empowerment and affective commitment

P. Yulianti \& N. Hamidah

The impact of transformational leadership, learning organization and job autonomy on creative self-efficacy

I. B. G. A. Permana \& W. Astiti

Enhancing commitment to organizational change initiative and performance outcomes N.A. Arina \& P. Yulianti

The influence of Perception of Usefulness (PoU) and Perceived Ease of Use (PEU) on the perception of information system performance

F. Sayekti \& L.E. Wijayanti

Knowledge sharing benefits: The contingency effects of environmental contexts

A. Qomariyah

The antecedents of entrepreneurial intentions in students of Airlangga university

(A study of student participants in WEBS in the faculty of economics and business)

P. Yulianti \& I. G.N.W.H. Saputra

Effect of proactive personality and Organizational Support for Career Development (OSCD) on career satisfaction and job performance

V. Octia \& D. Ratmawati

The effects of transformational and transactional leadership on work performance of middle-level leaders with organizational commitment as mediator: A study of state-owned company, Pelabuhan Indonesia III Inc.

A. Eliyana, S. Maarif \& R.J. Sunarsono 
Transformational leadership style, team performance and team job satisfaction:

Mediation by levels of cognitive trust and collective efficacy

P. Yulianti \& R. Sanjaya

The impact of self-efficacy and perceived organizational support on operational managers' readiness to change

H. Prima \& A. Eliyana

\section{Marketing management}

Factors affecting customer retention in a priority banking program

I.R. Aliyah, S. Soebandhi \& A. Baktiono

The impact of messages assertiveness on compliance with perceived importance as a moderation variable on the anti-cigarette campaign in Surabaya

Kristiningsih, R.S. Wuryaningrum \& A. Trimarjono

Demographic variables and environmentally friendly behavior in a developing country

T. Handriana

Antecedents and consequences of ongoing search information

D. T. Firmansyah \& D. Mardhiyah

Role of negative brand name perception and religiosity on brand attitude

S. Gunawan \& R.T. Ratnasari

The effects of good/bad news on consumer responses toward higher education

G.C. Premananto \& M.H. Hanafiah

Examining leadership style and advertising evaluation on employees'

customer focus

R.A. Aisyah \& N.A. Arina

The effect of airline sale promotion types on consumers' attitudes toward brand and purchase intentions

M. Kurniawati

The influence of celebgrams, e-WOM, and pictures on impulse buying

Hartini, Sri \& Uswatun

Value propositions of supermarkets

R. Rinawati

Empirical study of perceived quality information and perceived information security impact on online purchasing in Indonesia

L. Lisnawati, L.A. Wibowo \& P. Andi

Measuring religiosity and its effects on attitude and intention to wear a hijab:

Revalidating the scale

H.A. Wibowo \& M.R. Masitoh

\section{Management and economics education}

Communication skills of accountants and managers in Indonesia

Y.L. Rudianto \& A.R. Sridadi

Factors knowledge management and the work motivation of lecturers

Rino

The role of talent management in student performance in higher education

D. Purwaningsih

Strategy to build universities

P. Dewi Dirgantari, B. Widjajanta \& L. Lisnawati

Factors affecting the improvement of students' Grade Point Average (GPA)

A.B. Santoso, E.C.M. Simatupang \& R.H. Sofyandi 
Innovation, operations and supply chain management

Analysis of the small segment credit business process at Bank ABC Indonesia

A.C. Saifullah \& R.D. Kusumastuti

The identification of defects in rubber slipper production using the six sigma method

T.A. Auliandri \& M.A. Setiani

The design of service quality improvement in a library by using LibQUAL model and fishbone diagram

F. Wurjaningrum \& A. Kurniawan

The strategic role of Indonesia in Global Value Chains (GVC)

M.A. Esquivias, D. W. Sari \& R.D. Handoyo

N. Anridho

Efficiency and total-factor productivity in the manufacturing industry in

33 provinces of Indonesia

Muryani

Academic excellence and total quality supply chain management in higher education

I. Usman \& Windijarto

Financial management and accounting

The influence of usage accounting information on small medium enterprise's perception

S. Mintarti, D. M. Sari \& T. Fitriastuti

Determinants of banks' net interest margin in five South East Asian countries

M. Gitanadya \& R. Setiawan

The effect of monetary policy and macroeconomic variables on foreign portfolio investment in Indonesia

N.F. Anne \& R. Purwono

Internal factors, external factors, and bank liquidity in Indonesia

I.M. Sudana \& A.F. Akbar

The obstacles in developing Indonesia's sovereign sukuk

N. Laila, F.F. Hasib \& M. Anshori

The effect of trading volume changes on JKSE's market return

M. Madyan, S. Hasan \& D.F. Putri

The influence of the profitability indicator, capital and performing loans on the liquidity of the bank in the Indonesian stock exchange

O.V.B. Nainggolan

Corporate governance performance evaluation of banks operating in Indonesia

F. Budhijono

What drives finance pattern debt companies to pay dividends in Indonesia?

L. Gestanti \& G. Memarista

Diversification, firm value and government ownership

S. A. Usman \& C. Sulistyowati

Do operating costs, investment returns and claims have an effect on contributions?

D.F. Septiarini

S.R. Arifin \& Wisudanto

Different ways to solve the liquidity problem of Indonesian Islamic microfinance

I. Mawardi \& T. Widiastuti 
Determinant of banks stock risk in Indonesia

Degree of internationalization and firm financial performance

F. Ismiyanti

Cost efficiency of Indonesian banks over different groups of capital

M. Anwar

Analysis of investor preference in investing on initial public offering M. Sari

Female directors, nationality diversity, and firm performance: Evidence from the mining industry in Indonesia

Y.S. Putri, M. Nasih \& I. Harymawan

Sharia governance framework in Islamic banking and financial institutions in Indonesia:

A proposed structure

M.I.S. Mihajat

Mediating role of Investment Opportunity Set (IOS) on diversification-corporate value relationship: Empirical study of manufacturing companies in the IDX, 2013-2015

D. W.I. Hartono, B. Tjahjadi, N. Soewarno \& Y. Permatasari

Underpricing, operating performance, long-term market performance, and the probability of conducting seasoned equity offerings of IPO in Indonesian capital market

N. Sasikirono, Djumahir \& A. Djazuli

The effects of firm size, good corporate governance, and business risk towards financial performance with corporate social responsibility as the moderating variable N. Soewarno, E.S. Wulandari \& B. Tjahjadi

The effect of good corporate governance on financial performance with capital structure and earnings management as mediating variables

N. Soewarno, B. Tjahjadi \& B.D.P. Utomo

The impact of IFRS adoption on earnings management in the banking and mining sectors

H. Musvosvi

Managerial ownership and corporate diversification in the family and non-family businesses T. Perdana \& N. Fitdiarini

CEO gender, corporate finance decisions, and performance

R. H. Setianto \& J. Mahbubi

Empirical testing of the accuracy of various theory models to measure the value of the firm N.D. Kusumaningrum \& I. M. Narsa

Determinant variables of the performance rating of banks operating in Indonesia Sugiarto

Fraud prevention analysis in the financial management of local government

A. A. Nugroho \& Y.N. Supriadi

The effect of leverage and profitability on stock return: A study on the mining sector companies listed on the Indonesia stock exchange for the period 2011-2015

Y. Hendayana, H. Hari Mulyadi, Z. Musannip Efendi Siregar \&

A. Setyo Pranowo

Asymmetric information at first seasoned equity offering in the Indonesian capital market

H. Meidiaswati, Basuki \& A. Irwanto

Efficiency analysis of economic empowerment program in Surabaya National Amil Zakat Institution using Data Envelopment Analysis method (DEA)

F. Ramadhani \& E.F. Cahyono 


\title{
Determinants of banks' net interest margin in five South East Asian countries
}

\author{
M. Gitanadya \& R. Setiawan \\ Airlangga University, Surabaya, Indonesia
}

\begin{abstract}
South East Asian banking has different characteristics in each country and this affects the Net Interest Margin (NIM) acquired. Indonesian banks enjoy 5.4\% NIM, while Singaporean banks only acquired $1.4 \%$ in the same period. This study aims to determine the various factors that affect NIM in five South East Asian countries, which are Indonesia, Malaysia, Thailand, Singapore and the Philippines. There will be 11 independent variables grouped into three factors, which are bank-specific, industry and macroeconomics. The study will use a linear regression model. The result shows that South East Asia's NIM is affected significantly by relative size, credit risk, capital adequacy, diversification, industry concentration, short-term interest rate volatility and stock market capitalization. The study also concludes that capital markets and banks are both financial intermediaries that substitute for each other when their roles should be complementary in order to improve the respective country's economic condition.
\end{abstract}

\section{INTRODUCTION}

Banks have an important role as an intermediary institution in society. For that intermediary service, banks get Net Interest Margin (NIM), or the spread between interest incomes received from debtors and interest expenses paid to depositors, as the reward. A fascinating trend about NIM is that, in developed countries, banks are no longer relying solely on interest as the main source of income. The difference in dependency on NIM will affect a bank's rate of charged NIM to its customers.

Figure 1 shows that Indonesia has consistently provided the highest NIM during this study's period, followed by the Philippines, while Malaysia, Singapore and Thailand have relatively low and

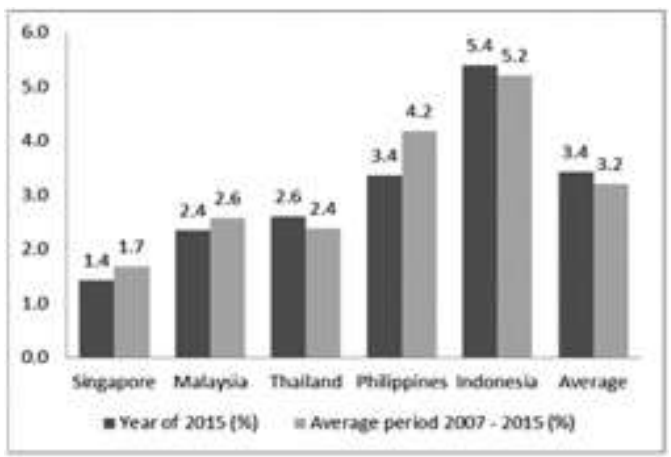

Figure 1. NIM data on five South East Asian banks for the year 2015 and the average in period 2007-2015. constant NIM. So, it will be intriguing to discover what variables influenced these differences of NIM among South East Asian countries.

Many previous researches have tried to outline NIM's determinants, with various countries and periods as objects. Those determinants can be categorized into three main factors, which are bank-specific, industry and macroeconomics factors. Those main factors have been researched independently, but not many have researched all three factors. One of those few was conducted by Islam and Nishiyama (2016) on the determinants of NIM in four South East Asian countries during 1997-2015. Its result showed that liquid assets, equity, required reserve and operational expenses, as bank-specific factors, impact NIM positively. Whereas both the bank's size and industry concentration have a negative influence. For the three variables from the macroeconomics factors tested, which were inflation, short-term interest rate and economic growth, this showed that only GDP growth affects NIM negatively and significantly.

Based on the background elaborated above, this research aims to see whether bank-specific factors, which consist of relative size, credit risk, liquidity, capital adequacy, operational risk and diversification; industry factors, which are represented by industry concentration; and macroeconomic factors, which consist of short-term interest rate volatility, inflation, PDB growth and stock market capitalization, influenced NIM in the five South East Asian countries, Indonesia, Malaysia, Thailand, Singapore and the Philippines, during 2007 to 2015 . These five countries are chosen because 
their total banking assets are a combined worth of US\$ 3.417 billion, representing $89 \%$ of the total South East Asian banking assets.

\section{LITERATURE ON DETERMINANTS OF NET INTEREST MARGIN}

\section{$2.1 \quad$ Net interest margin}

This research defines NIM according to Islam and Nishiyama (2016), which is the difference between interest income and cost divided by the bank's total assets to know the bank's net interest earning asset ability. Saunders (1997) investigated seven developed countries during 1988-1995 to see the effect of macroeconomic factors on the NIM acquired by banks. The result showed that the adjustment of reserve requirement from the central bank has a positive and significant relationship with NIM, where banks are exposed to the opportunity cost of reserves and set a higher loan rate to compensate. Saunders also found that a $1 \%$ increase in the short-term interest rate will see the NIM also surge by $0.2 \%$.

Fungacova and Poghosyan (2008) stated that a trade-off occurred between a bank's net interest margin and economic growth. The higher the margin that banks charged, the fewer the loans disbursed, which was caused by higher loan interest rates, and this will affect economic growth from either consumption or real sectors driven by bank loans. But, on the other hand, banks need higher margins to strengthen their capital and act as a buffer from any possible external shocks.

Valverde (2007) researched seven European countries during 1994-2005 and found that credit, liquidity and operational risks affect NIM positively and significantly. This is explained by the fact that banks can reassign the cost from those risks to customers by setting a higher loan rate and a lower deposit rate. Meanwhile, diversification has a negative effect towards NIM, caused by non-interest income that can replace a bank's interest revenue.

The banking industry has been regulated strictly because of its important role in the economy and mostly has an oligopoly market system where it is dominated by a few big players. Four Indonesian banks own $46 \%$ of the industry's assets, while Singapore's three main banks dominate the industry by a staggering $78 \%$.

There are many internal bank-specific factors that are determinants of NIM, such as a bank's relative size, credit risk, liquidity, capital adequacy, operational risk and income diversification. Industry factors are represented by industry competition or concentration that is measured with the Herfindahl Index. Macroeconomic factors that can influence NIM consist of short-term interest rate volatility, inflation rate, GDP growth and stock market capitalization from each country. These bank-specific, industry and macroeconomic factors are expected to comprehensively explain NIM.

\section{RESEARCH METHODS}

\subsection{Research model}

$$
\begin{aligned}
\text { NIM }_{\mathrm{i}, \mathrm{j}, \mathrm{t}}= & \mathrm{c}+\beta_{1} \text { RLSZ }_{\mathrm{i}, \mathrm{j}, \mathrm{t}}+\beta_{2} \mathrm{NPL}_{\mathrm{i}, \mathrm{j}, \mathrm{t}} \\
& +\beta_{3} \text { LQTA }_{\mathrm{i}, \mathrm{j}, \mathrm{t}}+\beta_{4} \mathrm{ETA}_{\mathrm{i}, \mathrm{j}, \mathrm{t}}+\beta_{5} \mathrm{EXP}_{\mathrm{i}, \mathrm{j}, \mathrm{t}} \\
& +\beta_{6} \mathrm{NII}_{\mathrm{i}, \mathrm{j}, \mathrm{t}}+\beta_{7} \mathrm{HHI}_{\mathrm{j}, \mathrm{t}}+\beta_{8} \mathrm{VOL}_{\mathrm{j}, \mathrm{t}} \\
& +\beta_{9} \mathrm{INF}_{\mathrm{j}, \mathrm{t}}+\beta_{10} \mathrm{PDB}_{\mathrm{j}, \mathrm{t}}+\beta_{11} \mathrm{KAP}_{\mathrm{j}, \mathrm{t}}+\varepsilon .
\end{aligned}
$$

\begin{tabular}{|c|c|}
\hline Variable & Description \\
\hline \multicolumn{2}{|c|}{ Dependent variable } \\
\hline NIM & $\begin{array}{l}\text { Difference between interest income and } \\
\text { interest expense over total assets }\end{array}$ \\
\hline \multicolumn{2}{|c|}{ Bank-specific independent variable } \\
\hline RLSZ & $\begin{array}{l}\text { Total assets of a bank compared to the } \\
\text { country's banking industry assets }\end{array}$ \\
\hline NPL & $\begin{array}{l}\text { Non-performing loan to outstanding loan } \\
\text { ratio }\end{array}$ \\
\hline LQTA & Liquid assets to total assets ratio \\
\hline ETA & Equity to total assets ratio \\
\hline EXP & Operational expenses to gross income ratio \\
\hline NII & $\begin{array}{l}\text { Non-interest expense less non-interest } \\
\text { revenue to total assets ratio }\end{array}$ \\
\hline \multicolumn{2}{|c|}{ Industry-specific independent variable } \\
\hline HHI & $\begin{array}{l}\text { Sum of squared market share of bank in a } \\
\text { country }\end{array}$ \\
\hline \multicolumn{2}{|c|}{ Macroeconomics independent variable } \\
\hline VOL & $\begin{array}{l}\text { Annual standard deviation of monthly } \\
\text { average of overnight interbank money } \\
\text { market rate }\end{array}$ \\
\hline INF & Annual inflation rate \\
\hline PDB & Annual GDP growth \\
\hline KAP & $\begin{array}{l}\text { The value of stock market capitalization } \\
\text { compared to the amount of money } \\
\text { deposited in banks }\end{array}$ \\
\hline
\end{tabular}

\subsection{Variables}

Table 1. Description of variables used in the study.

\subsection{Population and sample}

The object of this study is the banking in five South East Asian countries, which are Indonesia, Malaysia, Singapore, the Philippines and Thailand, during the years 2007 to 2015 . There were 21 banks observed in Indonesia, five banks in Malaysia, three banks in Singapore, nine banks in the Philippines and nine banks in Thailand, with a total sample of 47 banks across South East Asia. The banks used in this study should fulfill certain criteria, which are conventional commercial, nonsharia banks, own financial reports for every 31st 
December, and already listed in its respective country's stock market.

\section{RESULTS}

The bank-specific data are obtained from each bank's financial report. For industry and macroeconomic data, these are attained through each country's central bank report and the World Bank. Table 2 confirms this study's background on the difference of each South East Asian country's NIM. The average NIM for the South East Asian area is $3.33 \%$, in which Indonesia claims the highest NIM among these five countries with an average of $4.34 \%$, followed by Thailand with $2.81 \%$ and the Philippines with $2.73 \%$. Malaysian banks accomplish an average NIM of $2.1 \%$ and Singaporean banks have the lowest NIM with 1.31\%.

The regression model used in this study has fulfilled all of the classical assumption tests for regression in which the data have been normally distributed, free from any symptoms of autocorrelation, heteroskedasticity and multicollinearity. $\mathrm{H}_{0}$ proposed in this study means that there are no significant relationship between certain independent variable and NIM as the dependent one, and vice versa for $\mathrm{H}_{1}$. This study uses a significance rate of $5 \%$, so, if the regression result shows a significance of below $5 \%$ then $\mathrm{H}_{0}$ is rejected and $\mathrm{H}_{1}$ is accepted, and vice versa. Each independent variable will be discussed separately for its effect on NIM as a dependent variable for each country and South East Asia as whole.

NIM in Indonesian banking shows that it is significantly affected by relative size, liquidity, capital adequacy, operational risk and diversification. Meanwhile, the Malaysian banking industry indicates that relative size, credit risk, liquidity, capital adequacy, industry concentration and stock market capitalization affects NIM significantly.

Table 2. Descriptive statistics result for South East Asian banks.

\section{NIM RLSZ NPL LQTA ETA EXP NII}

$\begin{array}{llllllll}\text { MEAN } & 0.033 & 0.070 & 0.032 & 0.105 & 0.106 & 0.335 & 0.014\end{array}$

$\begin{array}{llllllll}\text { MAX } & 0.094 & 0.375 & 0.161 & 0.326 & 0.248 & 0.877 & 0.056\end{array}$

$\begin{array}{llllllll}\text { MIN } & 0.010 & 0.001 & 0.002 & 0.008 & 0.000 & 0.123 & 0.001\end{array}$ $\begin{array}{llllllll}\text { STDEV } & 0.014 & 0.073 & 0.025 & 0.064 & 0.031 & 0.092 & 0.008\end{array}$

\begin{tabular}{lccrrr}
\hline & HHI & VOL & \multicolumn{1}{c}{ INF } & \multicolumn{1}{c}{ PDB } & KAP \\
\hline MEAN & 0.064 & 0.394 & 4.378 & 5.000 & 1.176 \\
MAX & 0.152 & 1.112 & 11.060 & 15.240 & 2.471 \\
MIN & 0.007 & 0.006 & -0.895 & -1.514 & 0.507 \\
STDEV & 0.030 & 0.341 & 2.806 & 2.267 & 0.360 \\
\hline
\end{tabular}

Independent variables that significantly affect Thailand's NIM are credit risk, liquidity, diversification and industry concentration.

Whereas Singaporean banks exhibit their NIM as being significantly affected by relative size, liquidity, capital adequacy, operational risk and diversification, NIM in the Philippines is significantly affected by credit risk and liquidity only. For South East Asian banking overall, NIM is significantly affected by relative size, credit risk, capital adequacy, diversification, industry concentration, short-term interest rate volatility and stock market capitalization.

The result of regression analysis on these five countries, and on South East Asia as a whole, shows the relationship of NIM with 11 independent variables, with six of them being bank-specific ones consisting of relative size, credit risk, liquidity, capital adequacy, operational risk and diversification; industry concentration is the only industryspecific variable. Four macroeconomics variables, which are short-term interest rate volatility, inflation, GDP growth and stock market capitalization, are detailed in the table on the next page.

Relative size shows a significant and positive effect towards NIM in Indonesia and Singapore, a significant and negative effect in Malaysia and the South East Asia region, but it is insignificant in Thailand and the Philippines. This result matches the banking system in each country, where Indonesian and Singaporean banks are an oligopoly market, where three to four major banks hold more than $50 \%$ of the industry assets. Four major banks own $54 \%$ of Indonesia's banking assets, while Singapore's three major banks account for $78 \%$ of the assets of their industry. Meanwhile, the three other countries and the region itself have no major player that dominates the industry. It is proven that a bigger bank can claim higher NIM for governing the market.

Credit risk is affecting NIM negatively and significantly in Thailand and the South East Asia region, and this can be explained by the fact that Thailand's banks hold the highest NPL ratio among other countries by $4.42 \%$, resulting in detrimental effects on interest revenue and the banks' profit margins. Meanwhile, Malaysian and Philippine banks show a positive and significant relationship between NIM and credit risk. This is caused by these banks still being heavily dependent on NIM as a source of income, so the higher risk possessed by their loans will be transferred back as higher margins to their customers.

Most observations show that liquidity affects NIM positively, with the exception of the Philippine banks, which display a negative and significant result. This uniqueness is equivalent to the highest LQTA ratio in the Philippines as proxy for liquidity 
in the data collected. Bangko Sentra $\mathrm{Ng}$ Pilipinas, as its central bank, has set a bigger required reserve after the incidents in 2011 and 2012, when a massive shock hit the Philippine banks and forced 53 banks to go bankrupt. Even some major and old banks, such as Banco Pilipino (operating since 1964), Next Genesis Bank and Philippines Saving Bank, were closed or merged with other banks. This was caused by shortness in liquidity and internal fraud that had been ignored by the central banks for too long. Since then, Bangko Sentra Ng Pilipinas has undergone some major restructuring and improved the quality of Philippine banks. For the other four countries and the region, liquidity shows a positive effect towards NIM, which supports the results of Valverde and Fernandez's (2007) study, where the higher liquidity kept by banks allows them to set higher NIM for lowering the liquidity and solvency risk to their depositors.

All results for capital adequacy exhibited a positive relationship to NIM, in accordance with Fungacova and Poghosyan's (2008) study, which explained that the stronger the capital position owned, the less bankruptcy risk possessed by the banks, so they will be able to charge a higher risk premium to customers. Operational risks also indicated a constant and positive result in all of the countries researched. This agrees with Islam and Nishiyama (2016), who explained that all operational costs and risks will simply be switched as a higher profit margin for banks. But operational risk is only significant in Indonesia, while in the other countries it is not. This can be explained by the conventional banking system employed in Indonesia, which still relies heavily on ATM and branch service across the archipelago and does not maximize e-banking, unlike other countries.

Diversification affected NIM negatively in all of the observations. This result accords with Trinugroho's (2014) study, which found that diversification is a cross-subsidization strategy and results in a lower NIM being required with a higher rate of diversification. Even though this variable has the same direction, it differs in its significance across countries. Indonesia, Thailand, Singapore and the South East Asia region show a significant effect, but Malaysia and the Philippines do not. The significance dissimilarity can be traced from the proportion of NIM and NII across the countries, as shown in Table 4.

Table 3. Regression result.

\begin{tabular}{|c|c|c|c|c|c|c|}
\hline Variable & Indonesia & Malaysia & Thailand & Singapore & Philippines & $\begin{array}{l}\text { South East } \\
\text { Asia region }\end{array}$ \\
\hline Constanta & $\begin{array}{l}-0.031 \\
\quad(0.186)\end{array}$ & $\begin{array}{l}0.039^{*} \\
(0.000)\end{array}$ & $\begin{array}{l}0.041^{*} \\
(0.000)\end{array}$ & $\begin{array}{l}0.023^{*} \\
(0.000)\end{array}$ & $\begin{array}{l}0.025^{*} \\
(0.000)\end{array}$ & $\begin{array}{l}0.032^{*} \\
(0.000)\end{array}$ \\
\hline Relative size & $\begin{array}{l}0.103^{*} \\
(0.000)\end{array}$ & $\begin{array}{r}-0.013^{* *} \\
(0.026)\end{array}$ & $\begin{array}{c}-0.003 \\
(0.761)\end{array}$ & $\begin{array}{r}0.009 * * \\
(0.048)\end{array}$ & $\begin{array}{l}0.003 \\
(0.788)\end{array}$ & $\begin{array}{c}-0.051^{*} \\
(0.000)\end{array}$ \\
\hline Credit risk & $\begin{array}{l}-0.040 \\
(0.199)\end{array}$ & $\begin{array}{l}0.051^{*} \\
(0.002)\end{array}$ & $\begin{array}{r}-0.069^{*} \\
(0.000)\end{array}$ & $\begin{array}{l}-0.004 \\
(0.924)\end{array}$ & $\begin{array}{l}0.055^{*} \\
(0.002)\end{array}$ & $\begin{array}{r}-0.039 * \\
(0.004)\end{array}$ \\
\hline Liquidity & $\begin{array}{l}0.034^{*} \\
(0.001)\end{array}$ & $\begin{array}{l}0.023^{*} \\
(0.007)\end{array}$ & $\begin{array}{l}0.170^{*} \\
(0.002)\end{array}$ & $\begin{array}{l}0.011 \\
(0.148)\end{array}$ & $\begin{array}{r}-0.024^{*} \\
(0.002)\end{array}$ & $\begin{array}{c}0.012 * * * \\
(0.063)\end{array}$ \\
\hline Capital adequacy & $\begin{array}{l}0.139^{*} \\
(0.000)\end{array}$ & $\begin{array}{l}0.067^{*} \\
(0.009)\end{array}$ & $\begin{array}{l}0.009 \\
(0.592)\end{array}$ & $\begin{array}{l}0.024 \\
(0.301)\end{array}$ & $\begin{array}{l}0.003 \\
(0.835)\end{array}$ & $\begin{array}{l}0.039^{*} \\
(0.001)\end{array}$ \\
\hline Operational risk & $\begin{array}{l}0.067 * \\
(0.000)\end{array}$ & $\begin{array}{r}0.00003 \\
(0.996)\end{array}$ & $\begin{array}{c}0.011 * * * \\
(0.057)\end{array}$ & $\begin{array}{l}0.000 \\
(0.977)\end{array}$ & $\begin{array}{l}0.003 \\
(0.560)\end{array}$ & $\begin{array}{l}0.004 \\
\quad(0.320)\end{array}$ \\
\hline Diversification & $\begin{array}{l}-0.279^{*} \\
(0.000)\end{array}$ & $\begin{aligned}-0.210 \\
(0.272)\end{aligned}$ & $\begin{array}{c}-0.294^{*} \\
(0.000)\end{array}$ & $\begin{array}{r}-0.224^{* *} \\
(0.030)\end{array}$ & $\begin{array}{r}-0.029 \\
(0.570)\end{array}$ & $\begin{array}{r}-0.162^{*} \\
(0.001)\end{array}$ \\
\hline $\begin{array}{l}\text { Industry } \\
\text { concentration }\end{array}$ & $\begin{array}{c}0.623 * * * \\
(0.084)\end{array}$ & $\begin{array}{r}-0.020^{*} \\
(0.006)\end{array}$ & $\begin{array}{r}-0.085^{* *} \\
(0.011)\end{array}$ & $\begin{array}{c}-0.550^{*} \\
(0.000)\end{array}$ & $\begin{array}{l}0.020 \\
(0.559)\end{array}$ & $\begin{array}{r}-0.027 * * \\
(0.043)\end{array}$ \\
\hline $\begin{array}{l}\text { Short-term interest } \\
\text { rate volatility }\end{array}$ & $\begin{array}{l}0.000 \\
(0.926)\end{array}$ & $\begin{array}{l}-0.002 \\
\quad(0.287)\end{array}$ & $\begin{array}{l}0.002 \\
(0.464)\end{array}$ & $\begin{array}{l}0.004^{*} \\
(0.004)\end{array}$ & $\begin{array}{r}-0.001 \\
(0.729)\end{array}$ & $\begin{array}{l}0.008^{*} \\
(0.000)\end{array}$ \\
\hline Inflation & $\begin{array}{r}0.00001 \\
(0.954)\end{array}$ & $\begin{array}{r}-0.001 \\
\quad(0.185)\end{array}$ & $\begin{array}{l}0.000 \\
(0.176)\end{array}$ & $\begin{array}{l}0.000^{*} \\
(0.000)\end{array}$ & $\begin{array}{l}0.000 \\
(0.255)\end{array}$ & $\begin{array}{l}0.000^{*} \\
(0.000)\end{array}$ \\
\hline GDP growth & $\begin{array}{l}0.001 \\
(0.577)\end{array}$ & $\begin{array}{l}0.000 \\
(0.588)\end{array}$ & $\begin{array}{r}0.00007 \\
(0.710)\end{array}$ & $\begin{array}{r}0.00002 \\
(0.587)\end{array}$ & $\begin{array}{l}0.000 \\
(0.188)\end{array}$ & $\begin{array}{l}0.000 \\
(0.124)\end{array}$ \\
\hline $\begin{array}{l}\text { Stock market } \\
\text { capitalization }\end{array}$ & $\begin{array}{l}-0.003 \\
\quad(0.480)\end{array}$ & $\begin{array}{r}-0.009 * * \\
(0.030)\end{array}$ & $\begin{array}{l}-0.006 \\
\quad(0.131)\end{array}$ & $\begin{array}{l}-0.002^{*} \\
(0.002)\end{array}$ & $\begin{array}{c}-0.003 * * * \\
(0.073)\end{array}$ & $\begin{array}{l}-0.007^{*} \\
(0.000)\end{array}$ \\
\hline $\mathrm{R}^{2}$ & 0.604 & 0.761 & 0.620 & 0.903 & 0.608 & 0.607 \\
\hline Adjusted $\mathrm{R}^{2}$ & 0.576 & 0.676 & 0.553 & 0.832 & 0.539 & 0.595 \\
\hline
\end{tabular}

*: Significant at 1\%;**: Significant at 5\%; ***: Significant at 10\%. 
Table 4. NIM and NII proportion comparison.

\begin{tabular}{lll}
\hline Country & $\% \mathrm{NIM}$ & $\% \mathrm{NII}$ \\
\hline Indonesia & $77,12 \%$ & $22,88 \%$ \\
Malaysia & $73,96 \%$ & $26,04 \%$ \\
Thailand & $68,87 \%$ & $31,13 \%$ \\
Singapore & $59,28 \%$ & $40.72 \%$ \\
Philippines & $59,13 \%$ & $40.87 \%$ \\
South East & $70.62 \%$ & $29,38 \%$ \\
$\quad$ Asian region & & \\
\hline
\end{tabular}

The industry-specific variable has the same effect as relative size, because they both use the comparison of a bank's assets with its industry in the respective country. Indonesia's and the Philippines' banking show a positive and significant effect towards NIM because there are more than 100 operating banks in each country, with a higher degree of competition among those banks. This is in line with Ho and Saunders (1981), in that the closer the market system is to a monopoly, the higher NIM it will be able to charge to customers. The anomaly happened in Singapore, where relative size had a positive effect, while industry concentration had an opposite one. Singaporean banks are highly competitive, with only three major banks dominating the industry and no banks able to set higher NIM. This is proven with the highest HHI score in Singapore among the other countries.

The movement of short-term interest rates has a positive and significant effect towards NIM in Singapore and the South East Asia region. This can be explained because the Singapore Interbank Overnight Rate (SIBOR) is mainly used as the standard for many securities and derivative transactions in Singapore, not only for conventional banking; as such, it greatly affects NIM in Singapore. The contrast is shown in Indonesia, where it has no effect on its NIM because it has the highest average volatility. If it is too volatile, banks can not anticipate its movement and redistribute its effect on NIM. Indonesia is also dominated by conventional banking, as mentioned in the background of this study.

Inflation shows a positive effect in all of the observations, but it is only significant in Singapore and the South East Asia region and is insignificant in the other countries observed. This result matches with Demirgüç-Kunt and Huizinga (1999), who stated that the government of a country will try to subdue inflation by increasing its interest rate and this will affect banks to set a higher NIM.

All observations showed an insignificant result for the effect of GDP growth towards NIM. It is a relief to see that South East Asian banks are resilient to shocks in macroeconomics because, in some of the years observed, recession occurred. Even if the GDP is decreasing, banks are still able to make
Table 5. Stock market data for South East Asia in 2015.

\begin{tabular}{lll}
\hline $\begin{array}{l}\text { Country } \\
\text { and region }\end{array}$ & $\begin{array}{l}\text { Stock market } \\
\text { capitalization } \\
\text { (Billions USD) }\end{array}$ & $\begin{array}{l}\text { Comparison of stock } \\
\text { market capitalization } \\
\text { to GDP (\%) }\end{array}$ \\
\hline Indonesia & 347 & 41 \\
Malaysia & 380 & 129 \\
Thailand & 368 & 81,7 \\
Singapore & 639 & 218,6 \\
Philippines & 238 & 88,3 \\
South East & 2.022 & 78,4 \\
$\quad$ Asia & & \\
\hline
\end{tabular}

a positive NIM. A strong and resilient banking system will support continuous economic growth, both from its financial and real assets.

The last variable observed is the capitalization of the stock market. All of the observations have confirmed that the stock market acts as a substitution for banks, meaning that companies are no longer dependent on banks for fresh funds. Companies have other options by issuing securities through the capital market. The role of the capital market as a bank's competitor will restrain a bank's ability to charge higher NIM in order to attract companies requesting loans.

Table 5, below, shows the data of each country's observed capital market in 2015, collected from the World Bank.

Table 5 strengthens this study's finding that the more significant the result, the higher the country's ratio of stock marketcapitalization to GDP. Theleast significant countries are Indonesia and Thailand, which matches the lowest ratio and signifies the much-needed development of the stock market in both countries.

The model used in this study has a particularly high goodness of fit score or R2. This model has successfully explained $60.7 \%$ of variability in NIM movements in the South East Asia region. The highest R2 score belongs to Singapore and it can be interpreted that the model only missed less than $10 \%$ of NIM's variability in Singapore.

\section{CONCLUSION}

Based on the study conducted in 47 commercial banks across five South East Asian countries during 2007-2015, it can be concluded that the bankspecific factors that significantly affect NIM in the region are relative size, credit risk and diversification inversely, while capital adequacy has a positive effect. Industry concentration also has a negative and significant effect towards NIM. The macroeconomic factor that has a positive and significant effect towards NIM is short-term interest 
rate volatility, while stock market capitalization has an inversely significant effect. Capital adequacy, operational risk and GDP growth affect NIM positively in all of the countries observed, but they differ in their significance rate. However, diversification and stock market capitalization are inversely affecting NIM, only differing in their significance rate among those observed countries.

The differences in the required return set by banks from their lending and saving activities across the South East Asian countries are caused by the dissimilarity in economic conditions, government regulation, a bank's leniency to govern its internal system, diversification strategy and the financial services that banks are allowed to enact. This study would like to notify South East Asian banks to pay more attention towards a bank's relative size, default loans, capital adequacy and diversification strategy, which have a significant effect towards their NIM. Banks with persistent profit and return will help to strengthen the economic system of a country.

Lastly, capital markets and banks are financial intermediaries that could serve as complementary to each other and improve the respective country's economic condition. Nowadays, the role is still substitutionary when it should be complementary in order to acquire more comprehensive information on prospective debtors or issuers.

For future research, it is advised to add more observations caused by the limitations of sampling procedure in this study. The higher observation numbers will increase the model's reliability to explain NIM in banking.

\section{REFERENCES}

Almarzoqi, R. \& Naceur, S. B. (2015). Determinants of bank interest margins in the Caucasus and Central Asia (IMF Working Paper no. 15/87). Retrieved from https:// www.imf.org/en/Publications/WP/Issues/2016/12/31.

Angbazo, L. (1988). The determinants of bank interest margin: Default risk, interest rate risk and off balance sheet banking. Journal of Banking and Finance, 21, 55-87.

Athanasoglou, P. P., Brissimisa, S. N. \& Delisc, M. D. (2008). Bank-specific, industry specific and macro economic determinants of bank profitability. Journal of International Financial Markets, Institutions and Money, 18, 121-136.

Busch, R. \& Memmel, C. (2015). Bank's net interest margin and the level of interest rates (Bundesbank Discussion Paper 16), Deutsche Bundesbank Research Center.
Chansarn, S. (2014). Total factor productivity of commercial banks in Thailand. International Journal of Business and Society, 15(2).

Covas, F. B., Rezende, M. \& Vojtech, C. M. (2015). Why are net interest margins of large banks so compressed? Retrieved from https://www.federalreserve.gov/econresdata/notes/feds-notes/2015/why-are-net-interestmargins-of-large-banks-so-compressed-20151005.html.

Demirgüç-Kunt, A. \& Huizinga, H. (1999). Determinants of commercial bank interest margin and profitability: Some international evidence. Development Research Group, The World Bank Volume Agustus 1998.

Deorukhar, S. \& Xia, L. (2015). ASEAN: Deciphering the region's banking sector (BBVA Research on Asia Banking Watch December 2015). Retrieved from. http://www.bbvaresearch.com.

Fungacova, Z. \& Poghosyan, T. (2008). Determinants of bank interest margins in Russia: Does bank ownership matter? Research in International Business and Finance, 24.

Hawtrey, K. \& Liang, H. (2008). Bank interest margins in OECD Countries. Journal of Economic Finance, 19, 249-260.

Ho, T. S. Y. \& Saunders, A. (1981). The determinants of bank interest margin: Theory and empirical evidence. Journal of Financial Quantitative Analysis, 16, 581-600.

Islam, M. S. \& Nishiyama, S. (2016). The determinants of bank net interest margin: A panel evidence from South Asian Countries. Research in International Business and Finance, 37, 501-514.

Kosmidou, K., Tanna, S. \& Pasiouras, F. (2012). Determinants of profitability of domestic UK commercial banks: Panel evidence from the period 1995-2010 (Economics, Finance and Accounting Applied Research, Working Paper Series), Coventry University Business School.

Maudos, J. \& Guevara, J. F. (2004). Factors explaining the interest margin in the banking sectors of the European Union. Journal of Banking and Finance, 28, 2259-2281.

Saunders, A. \& Schumacher, L. (1997). The determinants of bank interest rate margins: An international study. NYU Stern Department of Finance Working Paper Series. South East Asia Network for Development. 2015. AFAS on Financial Services. Retrieved from http://www.seanet.com/.

Torres, T. (2012). Fiasco in our banks: What went wrong? Retrieved from http://philstar.com/headlines/ 2012/09/15/849205.

Trinugroho, I. A. A. \& Tarazi, A. (2014). Why have bank interest margins been so high in Indonesia since the 1997/1998 financial crisis? Research in International Business and Finance, 32, 139-158.

Valverde, S. C. \& Fernandez, F. R. (2007). The determinants of bank margins in European banking. FUNCAS Department of Economics, University of Granada Spain.

Williams, B. (2007). Factors determining net interest margins in Australia: Domestic and foreign banks. Finance Markets Institutions and Instruments, 16(3), pp. $145-156$. 